\title{
Research on the Performance Evaluation of Ideological and Political Education of College Students Based on Fuzzy Comprehensive Evaluation*
}

\author{
Xiuyin Bai ${ }^{1}$ \\ Chengdu University
}

\begin{abstract}
The smooth development of ideological and political education in colleges and universities requires the establishment of a relatively perfect performance evaluation system of ideological and political education, which is of great significance for strengthening the construction of the basic theory of ideological and political education in colleges and universities and promoting the improvement of the quality of ideological and political education in China. Based on the fuzzy evaluation method, this paper establishes the performance evaluation index system of ideological and political education for college students in China, which mainly includes 14 indexes in five aspects such as education process, policy implementation, subject, information system, input and environment. Based on the case study of Harbin University of Engineering in Heilongiiang Province, it is concluded that the results of ideological and political education performance evaluation are excellent, thus providing useful reference for the practice of ideological and political education performance evaluation in colleges and universities and effectively solving the fuzziness and uncertainty in the performance evaluation of ideological and political education in colleges and universities.
\end{abstract}

\section{Keywords}

Ideological and Political Education for college Students • Fuzzy Evaluation Method • Performance Evaluation

\footnotetext{
* This work was supported by key projects of Sichuan Regional Public Management Information Research Centre, Research on the accuracy supply of basic public service in the micro Era (QGXH17-02) supported by Training Program for Young and Middle-aged Key Teachers of Chengdu University of Technology (Serial No.: JXGG201522)

${ }^{1}$ Correspondence to: Xiuyin Bai (PhD), College of Law of Chengdu University of Technology, Chengdu 610059, China.

Email: baixiuyin@163.com
}

Citation: Bai, X. Y. (2018). Research on the Performance Evaluation of Ideological and Political Education of College Students Based on Fuzzy Comprehensive Evaluation. Educational Sciences: Theory \& Practice, 18(5), 2394-2402. http://dx.doi.org/10.12738/estp.2018.5.138 
In the Opinions on Further Strengthening and Improving the Ideological and Political Education of College Students" issued by the State Council in 2004, it is pointed out that improving the ideological and political education of college students is of great strategic significance, and the ideological and political education of college students should be included in the educational evaluation system of colleges and universities. This fully shows that the state attaches great importance to the ideological and political education of college students (Lee, et al., 2018). The smooth development of ideological and political education in colleges and universities requires the establishment of a relatively perfect performance evaluation system of ideological and political education, which is of great significance for strengthening the construction of the basic theory of ideological and political education in colleges and universities and promoting the improvement of the quality of ideological and political education in China. The establishment of an effective performance evaluation system for ideological and political education can not only effectively evaluate the current development of ideological and political education, but also summarize the disadvantages and shortcomings of the current ideological and political education, so as to provide scientific basis for the continuous improvement of ideological and political education and promote the improvement of the quality of ideological and political education in colleges and universities in China (Bai, Rajput, Hussain \& Khoja, 2014). Based on the fuzzy evaluation method, this paper establishes the performance evaluation index system of ideological and political education for college students in China, and effectively solves the problems of fuzziness and uncertainty in the performance evaluation of ideological and political education in colleges and universities, so as to make the performance evaluation of ideological and political education in colleges and universities more scientific and operable.

\section{Constructing Performance Evaluation Index System of Ideological and Political Education in Colleges and Universities Based on Fuzzy Comprehensive Evaluation Method}

\section{Brief Introduction to Fuzzy Comprehensive Evaluation Method}

The fuzzy comprehensive evaluation method provides some evaluation methods for the practical comprehensive evaluation problem by using some concepts of fuzzy mathematics. In particular, fuzzy comprehensive evaluation is a method of comprehensive evaluation of the status of subordinated levels of objects to be evaluated from a number of factors based on fuzzy mathematics, with the principle of fuzzy relation synthesis to quantify some factors that are not easy to be quantified, and convert qualitative evaluation into quantitative evaluation (Kemp \& Daily, 2007). The result of fuzzy comprehensive evaluation method is clear and systematic. It can solve the problem which is difficult to be quantified well. It is a good method to solve non-deterministic problems. The analysis procedure of the fuzzy comprehensive evaluation method is shown in Figure 1.

\section{Construction of performance evaluation index system of ideological and political education}

The performance evaluation of ideological and political education in colleges and universities is a very complicated process, which requires the comprehensive analysis and evaluation on education process, policy 
$\overline{\text { implementation, subject, information system, input and environment of ideological and political education in }}$ colleges and universities (Suresh \& Mujumdar, 2004), as shown in Figure 2.

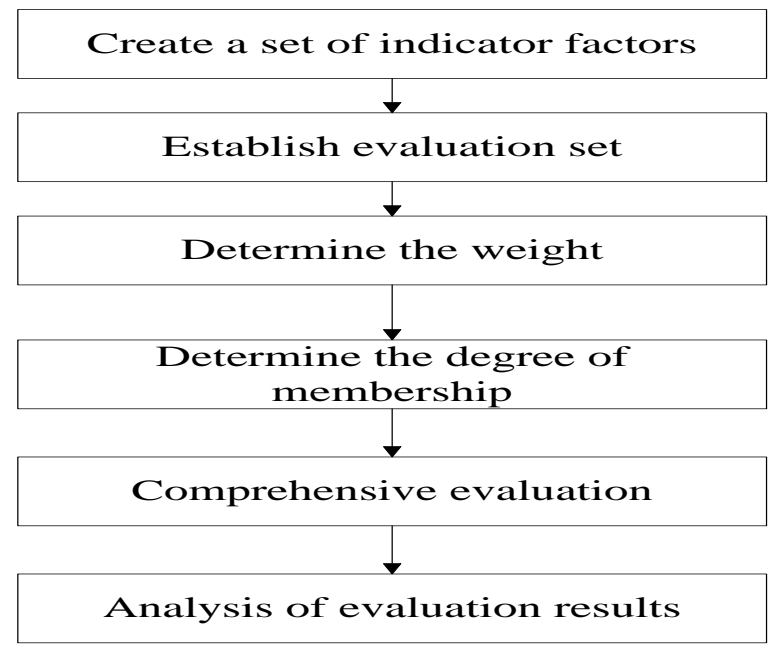

Figure 1. List of steps for comprehensive evaluation of steamed buns.

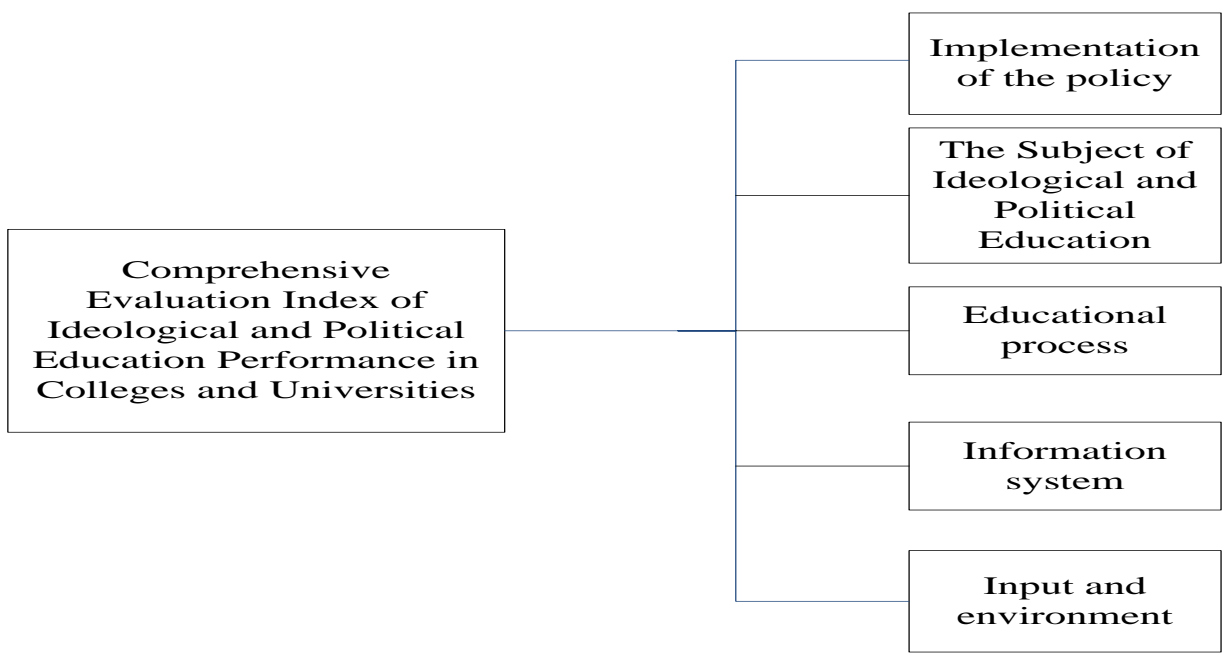

Figure 2. Performance Evaluation System of Ideological and Political Education.

\section{Analysis on Performance Evaluation of Ideological and Political Education in Colleges and Universities}

In order to better apply the performance evaluation index system of ideological and political education in colleges and universities, this paper chooses Harbin Engineering University in Heilongjiang Province as an example to evaluate the performance of ideological and political education. 


\section{Determination of index weight}

In the performance evaluation of ideological and political education in colleges and universities, the importance of each index is different and needs to be weighted (Koo, Kim, Cho \& Jang, 2012). In this paper, the experts in ideological and political education are invited to discuss, and a judgment matrix is formed by comparing the indexes at different levels. The results after comparison between two of the first-level indexes are shown in Table 2.

Among them, the process of ideological and political education in colleges and universities mainly includes systematic, scientific and creative planning; policy implementation includes institution setting, staffing, etc.; the subject includes the improvement in teachers' quality level and students' ideological and political consciousness; information system mainly includes information collection, management, analysis and so on; the environment includes both internal and external aspects. The performance evaluation index system of ideological and political education is shown in Table 1.

Table 1

Performance Evaluation Index System of Ideological and Political Education

\begin{tabular}{lll}
\hline Target layer & \multicolumn{1}{c}{ Criterion layer } & \multicolumn{1}{c}{ Sub - criterion layer } \\
\hline & $\begin{array}{l}\text { Implementation } \\
\text { of the policy(U1) }\end{array}$ & $\begin{array}{l}\text { Institutional settings(U11) } \\
\text { Staffing(U12) } \\
\text { Development planning(U13) } \\
\text { The Improvement of Educated People's Ideological } \\
\text { and Political Consciousness(U21) }\end{array}$ \\
$\begin{array}{l}\text { The Subject of } \\
\text { Comprehensive }\end{array}$ & $\begin{array}{l}\text { Ideological and } \\
\text { Evaluation }\end{array}$ & $\begin{array}{l}\text { Thoughts(U22) } \\
\text { Index of Ideological }\end{array}$ \\
$\begin{array}{l}\text { Political Education } \\
\text { and }\end{array}$ & The Quality and Structure of Educators(U23) \\
$\begin{array}{l}\text { Political Education } \\
\text { Performance }\end{array}$ & Educational & Systematization of educational programs(U31) \\
in Colleges and & process(U3) & Scientific nature of educational procedures(U32) \\
Universities(U) & Information & Information collection and management(U41) \\
& system(U4) & Information analysis and application(U42) \\
& Input and & Investment situation(U51) \\
& Internal environment(U52) \\
& environment(U5) & External environment(U53) \\
\hline
\end{tabular}

The judgment matrix can be obtained from Table 2 as follows:

Table 2

Level 1 Index Weight Set

\begin{tabular}{lccccc}
\hline & $\mathrm{U}_{1}$ & $\mathrm{U}_{2}$ & $\mathrm{U}_{3}$ & $\mathrm{U}_{4}$ & $\mathrm{U}_{5}$ \\
\hline $\mathrm{U}_{1}$ & 1 & $1 / 3$ & $1 / 6$ & $1 / 4$ & $1 / 5$ \\
$\mathrm{U}_{2}$ & 3 & 1 & $1 / 4$ & $1 / 5$ & 4 \\
$\mathrm{U}_{3}$ & 6 & 4 & 1 & 6 & 3 \\
$\mathrm{U}_{4}$ & 4 & 5 & $1 / 6$ & 1 & 5 \\
$\mathrm{U}_{5}$ & 5 & $1 / 4$ & $1 / 3$ & $1 / 5$ & 1 \\
\hline
\end{tabular}




$$
\mathrm{A}=\left[\begin{array}{ccccc}
1 & \frac{1}{3} & \frac{1}{6} & \frac{1}{4} & \frac{1}{5} \\
3 & 1 & \frac{1}{4} & \frac{1}{5} & 4 \\
6 & 4 & 1 & 6 & 3 \\
4 & 5 & \frac{1}{6} & 1 & 5 \\
5 & \frac{1}{4} & \frac{1}{3} & \frac{1}{5} & 1
\end{array}\right]
$$

The maximum eigenvalue of the judgment matrix can be calculated as $\lambda \max =5.531$ by the method of root finding.

However, when experts perform the grading evaluation, it's inevitable to have the subjective influence and it's easy to have the one-sidedness. In order to reduce the influence of this situation, it is necessary to carry out the consistency test (Chen, 2014). First, the consistency index CI is calculated:

$$
\mathrm{CI}=\frac{\lambda_{\max }-\mathrm{m}}{\mathrm{m}-1}=\frac{5.531-5}{5-1}=0.133
$$

The mean random consistency index RI is then looked up, and the specific values are shown in Table 3.

Table 3

RI Value Corresponding to Order $M$

\begin{tabular}{lllllllll}
\hline $\mathrm{m}$ & 1 & 2 & 3 & 4 & 5 & 6 & 7 & 8 \\
\hline $\mathrm{RI}$ & 0 & 0 & 0.54 & 0.91 & 1.15 & 1.28 & 1.37 & 1.42 \\
\hline
\end{tabular}

A consistency ratio of 0.115 can be obtained from $C R=C I / R I$. If $C R<0.1$, indicating that the consistency of the judgment matrix is acceptable (Park \& Cho, 2010), so the judgment matrix satisfies the consistency check, which shows that the weight of the first-level indexes of the performance evaluation of ideological and political education in colleges and universities are credible. The first-level index weight set: W = [W1, W2, W3, W4, $\mathrm{W} 5]=[0.193,0.412,0.206,0.174,0.015]$.

According to the above calculation steps, the weights in the secondary indexes can be sequentially calculated and the consistency check can be performed, and the specific results are shown in Table 4-Table 8.

Table 4

Level 2 Indicators - Implementation of the Policy Weight Set

\begin{tabular}{lccccc}
\hline Level 1 indicators & Level 2 indicators & $\mathrm{U}_{11}$ & $\mathrm{U}_{12}$ & $\mathrm{U}_{13}$ & Indicator weight \\
\hline \multirow{3}{*}{ Implementation of the policy (0.193) } & $\mathrm{U}_{11}$ & 1 & 3 & 2 & $39.6 \%$ \\
& $\mathrm{U}_{12}$ & $1 / 3$ & 1 & 1 & $36.8 \%$ \\
& $\mathrm{U}_{13}$ & $1 / 2$ & 1 & 1 & $23.6 \%$ \\
\hline
\end{tabular}

$\mathrm{CR}=0.074<0.1$, The consistency of the judgment matrix is acceptable

Table 5

Level 2 Indicators - The Subject of Ideological and Political Education Weight Set

\begin{tabular}{lccccc}
\hline \multirow{2}{*}{ Level 1 indicators } & $\begin{array}{c}\text { Level 2 } \\
\text { indicators }\end{array}$ & $\mathrm{U}_{21}$ & $\mathrm{U}_{22}$ & $\mathrm{U}_{23}$ & $\begin{array}{c}\text { Indicator } \\
\text { weight }\end{array}$ \\
\hline \multirow{3}{*}{ The Subject of Ideological and Political Education (0.412) } & $\mathrm{U}_{21}$ & 1 & 2 & 3 & $31.7 \%$ \\
& $\mathrm{U}_{22}$ & $1 / 2$ & 1 & $1 / 3$ & $35.4 \%$ \\
& $\mathrm{U}_{23}$ & $1 / 3$ & 3 & 1 & $32.9 \%$ \\
\hline
\end{tabular}

$\mathrm{CR}=0.089<0.1$, The consistency of the judgment matrix is acceptable 
Table 6

Level 2 Indicators - Educational Process Weight Set

\begin{tabular}{lccccc}
\hline Level 1 indicators & Level 2 indicators & $\mathrm{U}_{31}$ & $\mathrm{U}_{32}$ & $\mathrm{U}_{33}$ & Indicator weight \\
\hline & $\mathrm{U}_{31}$ & 1 & 2 & $1 / 3$ & $36.4 \%$ \\
Educational process (0.206) & $\mathrm{U}_{32}$ & $1 / 2$ & 1 & 2 & $30.8 \%$ \\
& $\mathrm{U}_{33}$ & 3 & $1 / 2$ & 1 & $32.8 \%$ \\
\hline
\end{tabular}

$\mathrm{CR}=0.093<0.1$, The consistency of the judgment matrix is acceptable

Table 7

Level 2 Indicators - Information System Weight Set

\begin{tabular}{lcccc}
\hline Level 1 indicators & Level 2 indicators & $\mathrm{U}_{41}$ & $\mathrm{U}_{42}$ & Indicator weight \\
\hline \multirow{2}{*}{ Information system $(0.174)$} & $\mathrm{U}_{11}$ & 1 & 3 & $41.7 \%$ \\
& $\mathrm{U}_{12}$ & $1 / 3$ & 1 & $58.3 \%$ \\
\hline
\end{tabular}

$\mathrm{CR}=0.082<0.1$, The consistency of the judgment matrix is acceptable

Table 8

Level 2 Indicators - Input and Environment Weight Set

\begin{tabular}{lccccc}
\hline Level 1 indicators & Level 2 indicators & $\mathrm{U}_{51}$ & $\mathrm{U}_{52}$ & $\mathrm{U}_{53}$ & Indicator weight \\
\hline & $\mathrm{U}_{51}$ & 1 & $1 / 4$ & 3 & $29.6 \%$ \\
Input and environment (0.015) & $\mathrm{U}_{52}$ & 4 & 1 & 2 & $40.3 \%$ \\
& $\mathrm{U}_{53}$ & $1 / 3$ & $1 / 2$ & 1 & $30.1 \%$ \\
\hline
\end{tabular}

$\mathrm{CR}=0.087<0.1$, The consistency of the judgment matrix is acceptable

\section{Single factor evaluation matrix}

According to the results of questionnaire, the membership degree of each index grade can be obtained, and then the fuzzy relation matrix can be obtained, so as to calculate the result of fuzzy comprehensive evaluation (Hussain, 2006).

From Table 4, it can be concluded that the fuzzy comprehensive evaluation set for policy implementation:

$\mathrm{W} 1=[\mathrm{W} 11, \mathrm{~W} 12, \mathrm{~W} 13]=[0.396,0.368,0.236]$

$\mathrm{B} 1=[0.531,0.348,0.121]$

Using the same calculation method, it can be found that:

The fuzzy comprehensive evaluation set of the subject of ideological and political education is B2 $=[0.506$, $0.383,0.111]$

The fuzzy comprehensive evaluation set of educational process is B3=[0.482, 0.371, 0.147]

The fuzzy comprehensive evaluation set of information system is B4=[0.464, 0.439, 0.097]

The fuzzy comprehensive evaluation set of input and environment is B5=[0.488, $0.376,0.136]$ 


\section{Fuzzy comprehensive evaluation}

The evaluation grade field V $=[\mathrm{V} 1, \mathrm{~V} 2, \mathrm{~V} 3]=$ [excellent, general, poor $]$ for the performance evaluation of ideological and political education in this study corresponds to the fuzzy data table shown in Table 9.

Table 9

Language Comment Set Conversion Standard

\begin{tabular}{lccc}
\hline \multicolumn{1}{l}{ Symbol } & Language comment set & Symbol & Triangular fuzzy number \\
\hline $\mathrm{V}_{1}$ & Excellent & $\mathrm{D}_{1}$ & $(70,85,90)$ \\
$\mathrm{V}_{2}$ & Average & $\mathrm{D}_{1}$ & $(50,65,85)$ \\
$\mathrm{V}_{3}$ & Poor & $\mathrm{D}_{1}$ & $(30,50,75)$ \\
\hline
\end{tabular}

Then, we can calculate the performance evaluation results of the implementation of ideological and political education policy:

First, the set of triangle fuzzy number conversion comments is obtained as follows: $\mathrm{M} 1=\mathrm{B} 1 \times \mathrm{V}=(85.33$ 68.24 19.45)

Secondly, a comparative analysis is carried out with the evaluation results as follows: D11=82.33, $\mathrm{D} 12=74.52$ and D13=72.15, where value of D11 is the highest.

In accordance with the maximum degree of membership principle, D11 can represent the final result of this evaluation element (Maria et al., 2009), thus, the performance evaluation result of the implementation of the ideological and political education policy of Harbin University of Engineering in Heilongjiang Province is excellent.

With the same method, we can finally find out that the performance evaluation results of ideological and political education's subject, education process, information system, input and environment of Harbin Engineering University in Heilongjiang Province are excellent, excellent, general and excellent respectively.

Based on the above analysis, it can be concluded that the performance evaluation result of ideological and political education of Harbin University of Engineering in Heilongjiang Province is excellent.

\section{Enlightenment}

(1) Although the result of the performance evaluation of the ideological and political education of Harbin University of Engineering is excellent, there are still places in the ideological and political education that need to be improved and promoted. For example, the systematic weight of the ideological and political education program is relatively small, and although colleges and universities have made a lot of investment in ideological and political education, the overall planning and design is not systematic enough. In the future, senior leaders of colleges and universities will be required to carry out systematic planning.

(2) The performance evaluation of ideological and political education in colleges and universities is an important part of ideological and political education in colleges and universities. The process of performance evaluation is a process of two-way communication, which requires teachers and students to establish a good communication mechanism so as to ensure the effectiveness of performance evaluation (Ray et al., 2002). At 
the same time, the ultimate goal of performance evaluation is not to evaluate, but in the process of evaluation, fully absorb the opinions and suggestions of all aspects, and after evaluation, conduct communication, find out the disadvantages and shortcomings of ideological and political education, and analyze the reasons, so as to formulate effective and targeted countermeasures and suggestions and better improve the quality of ideological and political education in colleges and universities.

\section{Conclusion}

Based on the fuzzy evaluation method, this paper establishes the performance evaluation index system of ideological and political education of college students in China, and takes Harbin Engineering University in Heilongjiang Province as an example to carry on the case analysis, with the following conclusions below:

The performance evaluation of ideological and political education in colleges and universities is a very complicated process, and its evaluation index system mainly includes 14 indexes in such five aspects as education process, policy implementation, subject, information system, input and environment.

This paper evaluates the educational performance of ideological and political education in Harbin University of Engineering to obtain the evaluation result of excellence, thus providing useful reference for the practical performance evaluation of ideological and political education in colleges and universities, and effectively solving the fuzziness and uncertainty in the performance evaluation of ideological and political education in colleges and universities.

\section{References}

Bai, S., Rajput, Q., Hussain, S., \& Khoja, S. A. (2014, November). Faculty performance evaluation system: An ontological approach. In 2014 IEEE/ACS 11th International Conference on Computer Systems and Applications (AICCSA), 117-124. http://dx.doi. org/10.1109/aiccsa.2014.7073187

Chen, S. G. (2014). Linguistic performance evaluation for an ERP system with link failures. Information Sciences, 279(99), 229-238. http://dx.doi. org/10.1016/j.ins.2014.03.116

Hussain, I. (2006). Tu-ff-a4-02: diagnostic medical physics performance evaluation of a portable digital flat detector system. Medical Physics, 33(6), 2222-2222. http://dx.doi. org/10.1118/1.2241657

Koo, Y. S., Kim, S. T., Cho, J. S., \& Jang, Y. K. (2012). Performance evaluation of the updated air quality forecasting system for Seoul predicting pm10. Atmospheric Environment, 58(4), 56-69. http://dx.doi. org/10.1016/j.atmosenv.2012.02.004

Kemp, B., \& Daily, Q. A. (2007). PET/CT performance evaluation techniques and quality assurance. Medical Physics, 34(6Part19), 2580-2581. http://dx.doi. org/10.1118/1.2761474

Lee, C. S., Wang, M. H., Wang, C. S., Teytaud, O., Liu, J., Lin, S. W., \& Hung, P. H. (2018). PSO-based fuzzy markup language for student learning performance evaluation and educational application. arXiv preprint arXiv:1802.08822. http://dx.doi.org/10.1109/tfuzz.2018.2810814 
Bai / Research on the Performance Evaluation of Ideological and Political Education of College Students Based...

Mosquedaa, M. R. P., Tollnerb, E. W., Boyhanc, G. E., Lid, C. Y., \& McClendonb, R. W. (2009). Simulating onion packinghouse product flow for performance evaluation and education. Biosystems Engineering, 102(2), 135-142. http://dx.doi. org/10.1016/j.biosystemseng.2008.09.021

Park, S. S., \& Cho, S. Y. (2010). Performance evaluation of an in situ nitrous acid measurement system and continuous measurement of nitrous acid in an indoor environment. (technical paper) (report). Air Repair, 60(12), 1434-1442. http://dx.doi. org/10.3155/1047-3289.60.12.1434

Ray, S. S., Dadhwal, V. K., \& Navalgund, R. R. (2002). Performance evaluation of an irrigation command area using remote sensing: a case study of mahi command, Gujarat, India. Agricultural Water Management, 56(2), 81-91. http://dx.doi. org/10.1016/s0378-3774(02)00006-9

Suresh, K. R., \& Mujumdar, P. P. (2004). A fuzzy risk approach for performance evaluation of an irrigation reservoir system. Agricultural Water Management, 69(3), 159-177. http://dx.doi. org/10.1016/j.agwat.2004.05.001 